\title{
Flavobacterium xueshanense sp. nov. and Flavobacterium urumqiense sp. nov., two psychrophilic bacteria isolated from glacier ice
}

Correspondence

Yuhua Xin xinyh@im.ac.cn
Kun Dong, ${ }^{1,2}$ Hongcan Liu, ${ }^{1}$ Jianli Zhang, ${ }^{3}$ Yuguang Zhou ${ }^{1}$ and Yuhua Xin ${ }^{1}$

${ }^{1}$ CGMCC-China General Microbiological Culture Collection Center, Institute of Microbiology, Chinese Academy of Sciences, Beijing 100101, PR China

${ }^{2}$ China Agricultural University, Beijing 100193, PR China

${ }^{3}$ School of Life Science and Technology, Beijing Institute of Technology, Beijing 100081, PR China

Two Gram-stain-negative, rod-shaped bacteria, designated strains $\mathrm{Sr}_{22}{ }^{\top}$ and $\mathrm{Sr} 25^{\top}$, were isolated from water of melted ice from the China No.1 glacier, Xinjiang Uygur Autonomous Region, China. Cells formed yellow, circular, convex colonies. 16S rRNA gene sequence analysis indicated that strains $\mathrm{Sr} 22^{\top}$ and $\mathrm{Sr} 25^{\top}$ belong to the genus Flavobacterium, sharing $\leqslant 99.1$ and $\leqslant 99.6 \%$ similarity, respectively, with the type strains of recognized species of the genus. Strain $\mathrm{Sr} 22^{\top}$ shared highest $16 \mathrm{~S}$ rRNA gene sequence similarity with Flavobacterium tiangeerense CGMCC $1.6847^{\top}(98.6 \%)$, Flavobacterium fryxellicola LMG $22022^{\top}(98.1 \%)$ and

Flavobacterium omnivorum CGMCC $1.2747^{\top}$ (99.1\%). Strain $\mathrm{S} r 25^{\top}$ shared highest similarity with Flavobacterium sinopsychrotolerans CGMCC $1.8704^{\top}$ (98.5\%), Flavobacterium degerlachei NBRC $102677^{\top}(98.4 \%)$ and Flavobacterium xinjiangense CGMCC $1.2749^{\top}$ $(99.5 \%)$. The predominant fatty acids of strain $\mathrm{Sr}_{22}{ }^{\top}$ were iso- $\mathrm{C}_{15: 1} \mathrm{G}(6.01 \%)$, iso- $\mathrm{C}_{15: 0}$ (8.93\%), iso- $\mathrm{C}_{16: 1} \mathrm{H}(12.68 \%)$, iso- $\mathrm{C}_{16: 0}(10.4 \%), \mathrm{C}_{15: 1} \omega 6 \mathrm{c}(8.97 \%), \mathrm{C}_{17: 1} \omega 6 \mathrm{c}(5.96 \%)$, iso- $\mathrm{C}_{16: 0} 3-\mathrm{OH}(11.14 \%)$ and summed feature 3 (comprising $\mathrm{C}_{16: 1} \omega 7 \mathrm{c}$ and/or $\mathrm{C}_{16: 1} \omega 6 \mathrm{c}$, $12.33 \%)$. The major fatty acids of strain $\mathrm{Sr}^{\top} 5^{\top}$ were iso- $\mathrm{C}_{15: 0}(10.8 \%)$, anteiso- $\mathrm{C}_{15: 0}(5.23 \%)$, $\mathrm{C}_{15: 1} \omega 6 c(11.79 \%), \mathrm{C}_{17: 1} \omega 6 c(5.43 \%)$, iso- $\mathrm{C}_{16: 0} 3-\mathrm{OH}(7.04 \%)$ and summed feature 3 $(20.42 \%)$. The genomic DNA G $+C$ contents of strains $\mathrm{Sr}_{2}{ }^{\top}$ and $\mathrm{Sr} 25^{\top}$ were 37.2 and $35.1 \mathrm{~mol} \%$. On the basis of differential phenotypic and phylogenetic characteristics, these strains are considered to represent two novel species of the genus Flavobacterium, for which the names Flavobacterium xueshanense sp. nov. (type strain $\operatorname{Sr} 22^{\top}=$ CGMCC $1.9227^{\top}=$ NBRC $106479^{\top}$ ) and Flavobacterium urumqiense sp. nov. (type strain $\mathrm{Sr}_{2} 5^{\top}=$ CGMCC $1.9230^{\top}=\mathrm{NBRC}$ $106480^{\top}$ ) are proposed.
The genus Flavobacterium belongs to the phylum Bacteroidetes (formerly the Cytophaga-Flavobacterium-Bacteroides group) (Bernardet et al., 2002). It was proposed by Bergey et al. (1923) and the description was revised by Bernardet et al. (1996). Members of the genus Flavobacterium are widespread and have been isolated from a wide range of habitats such as freshwater sediments (Tamaki et al., 2003), glacier ice (Zhu et al., 2003), Antarctic habitats (McCammon \& Bowman, 2000), soil (Yoon et al., 2006) and diseased fish (Bernardet \& Bowman, 2006). Recently, several bacteria isolated from the China No.1 glacier have been added to the genus Flavobacterium, such as Flavobacterium xinjiangense and

The GenBank/EMBL/DDBJ accession numbers for the 16S rRNA gene sequences of strains $\mathrm{Sr} 22^{\top}$ and $\mathrm{Sr} 25^{\top}$ are HQ436466 and HQ436467, respectively.

A supplementary figure is available with the online version of this paper.
Flavobacterium omnivorum (Zhu et al., 2003), Flavobacterium glaciei (Zhang et al., 2006) and Flavobacterium tiangeerense (Xin et al., 2009). In the present study, two novel strains, $\mathrm{Sr} 22^{\mathrm{T}}$ and $\mathrm{Sr} 25^{\mathrm{T}}$, isolated from the China No.1 glacier are characterized.

Strains $\operatorname{Sr} 22^{\mathrm{T}}$ and $\mathrm{Sr} 25^{\mathrm{T}}$ were isolated from water melted from glacier ice. They were isolated and cultivated aerobically at $14{ }^{\circ} \mathrm{C}$ on PYG agar (Zhang et al., 2006). Reference strains Flavobacterium degerlachei NBRC $102677^{\mathrm{T}}$, F. omnivorum CGMCC $1.2747^{\mathrm{T}}$, Flavobacterium sinopsychrotolerans CGMCC $1.8704^{\mathrm{T}}$, Flavobacterium fryxellicola LMG $22022^{\mathrm{T}}, F$. tiangeerense CGMCC $1.6847^{\mathrm{T}}$ and F. xinjiangense CGMCC $1.2749^{\mathrm{T}}$ were cultivated under the same conditions.

16S rRNA gene sequences were amplified by using universal primers 27f (5'-AGAGTTTGATCCTGGCTCAG-3') and 1492r (5'-TACGGCTACCTTGTTACGACTT-3') 


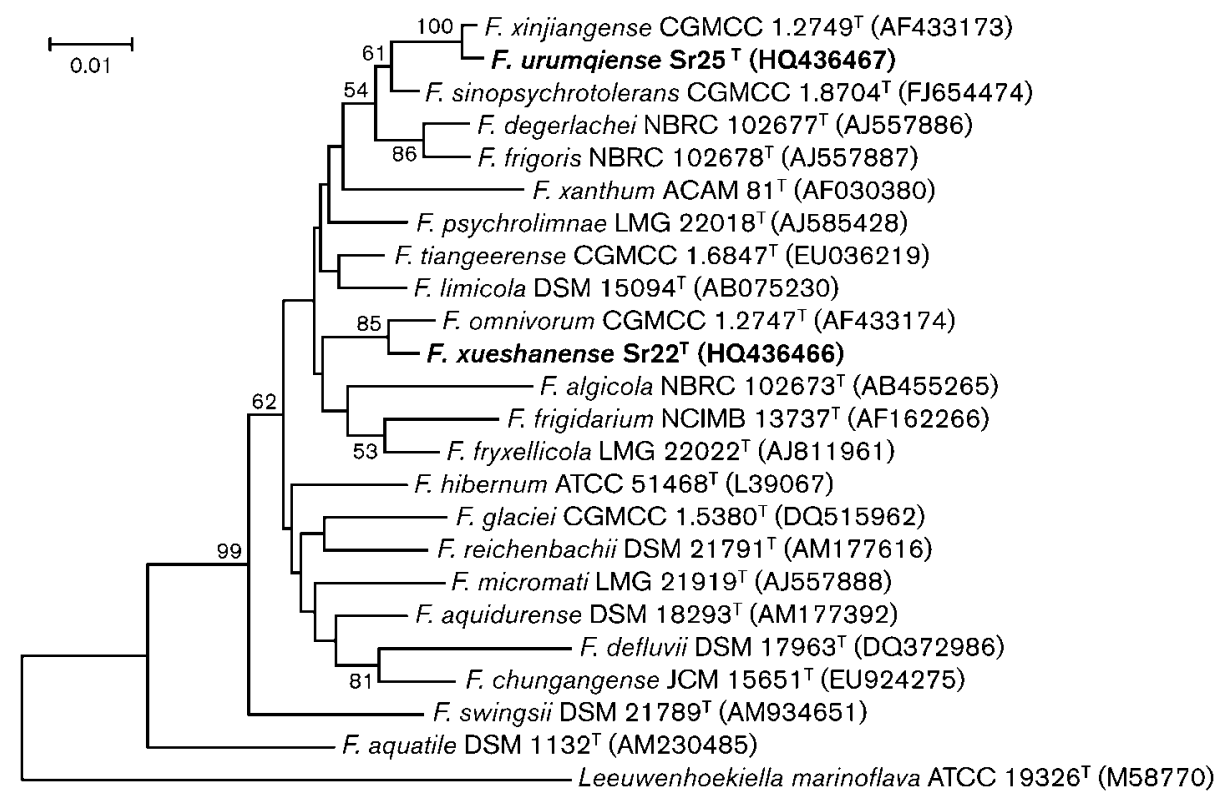

Fig. 1. Neighbour-joining tree based on $16 \mathrm{~S}$ rRNA gene sequences showing the phylogenetic relationship between strains $\mathrm{Sr} 22^{\top}$ and $\mathrm{Sr}_{25}{ }^{\top}$ and representative species of the genus Flavobacterium. The tree was rooted with the type strain of Leeuwenhoekiella marinoflava. Numbers at nodes represent bootstrap values (percentages of 1000 resampled datasets); only values $>50 \%$ are shown. GenBank accession numbers of $16 \mathrm{~S}$ rRNA gene sequences are given in parentheses. Bar, $0.01 \%$ sequence divergence.

(Lane, 1991). The amplified 16S rRNA gene fragments of strains $\mathrm{Sr} 22^{\mathrm{T}}$ and $\mathrm{Sr} 25^{\mathrm{T}}$ were sequenced by using the $\mathrm{ABI}$ BigDye3.1 Sequencing kit (Applied Biosystems) and an automated DNA sequencer (model ABI 3730XL; Applied Biosystems). The program BLASTN was used to compare $16 \mathrm{~S}$ rRNA gene sequences of strains $\mathrm{Sr} 22^{\mathrm{T}}$ and $\mathrm{Sr} 25^{\mathrm{T}}$ (1390 and $1392 \mathrm{nt}$, respectively) with others available from the GenBank and EMBL databases. Phylogenetic analysis was based on the neighbour-joining (Saitou \& Nei, 1987), maximum-likelihood (Felsenstein, 1981) and maximum-parsimony algorithms (Kimura, 1980) available in MEGA version 3.0 (Kumar et al., 2004). Bootstrap analysis (1000 replicates) was used to evaluate the topology of phylogenetic trees.

The results revealed that the novel strains shared $99.5 \%$ or less 16S rRNA gene sequence similarity with the type strains of recognized species of the genus Flavobacterium. Strains $\mathrm{Sr} 22^{\mathrm{T}}$ and $\mathrm{Sr} 25^{\mathrm{T}}$ shared 94.4 and $94.0 \% 16 \mathrm{~S}$ rRNA gene sequence similarity, respectively, with Flavobacterium aquatile DSM $1132^{\mathrm{T}}$ (the type species of the genus). Strain Sr $22^{\mathrm{T}}$ shared highest similarity with $F$. fryxellicola LMG $22022^{\mathrm{T}}(98.1 \%)$, F. tiangeerense CGMCC $1.6847^{\mathrm{T}}(98.6 \%)$ and F. omnivorum CGMCC $1.2747^{\mathrm{T}}(99.1 \%)$; strain Sr25 ${ }^{\mathrm{T}}$ shared highest similarity with $F$. sinopsychrotolerans CGMCC $1.8704^{\mathrm{T}}(98.5 \%)$, F. degerlachei NBRC $102677^{\mathrm{T}}$ $(98.4 \%)$ and $F$. xinjiangense CGMCC $1.2749^{\mathrm{T}}(99.5 \%)$. The level of similarity between strains $\mathrm{Sr} 22^{\mathrm{T}}$ and $\mathrm{Sr} 25^{\mathrm{T}}$ was $96.5 \%$. Fig. 1 shows the phylogenetic relationship between strains $\mathrm{Sr} 22^{\mathrm{T}}$ and $\mathrm{Sr} 25^{\mathrm{T}}$ and representative species of the genus Flavobacterium based on 16S rRNA gene sequences.
Genomic DNA was extracted according to the method of Marmur (1961). The G+C content was determined by the thermal denaturation method (Marmur \& Doty, 1962) by using genomic DNA from Escherichia coli $\mathrm{K}-12$ as reference. The DNA G $+\mathrm{C}$ content of strains $\mathrm{Sr} 22^{\mathrm{T}}$ and Sr $25^{\mathrm{T}}$ was 37.2 and $35.1 \mathrm{~mol} \%$, respectively.

DNA-DNA hybridization was performed based on the liquid renaturation method (De Ley et al., 1970) to determine the level of relatedness between the new isolates and their closest neighbours. A model Lambda 35 UV/VIS spectrometer equipped with a temperature programme controller (Perkin-Elmer) was used. Levels of DNA-DNA relatedness between strain $\mathrm{Sr} 22^{\mathrm{T}}$ and $F$. fryxellicola LMG $22022^{\mathrm{T}}, F$. tiangeerense CGMCC $1.6847^{\mathrm{T}}$ and F. omnivorum CGMCC $1.2747^{\mathrm{T}}$ were $23.6,25.9$ and $31.5 \%$, respectively; those between strain $\mathrm{Sr} 25^{\mathrm{T}}$ and $F$. sinopsychrotolerans CGMCC $1.8704^{\mathrm{T}}, F$. degerlachei NBRC $102677^{\mathrm{T}}$ and $F$. xinjiangense CGMCC $1.2749^{\mathrm{T}}$ were 24.6 , 34.9 and $40.6 \%$, respectively. These data demonstrated that strains $\mathrm{Sr} 22^{\mathrm{T}}$ and $\operatorname{Sr} 25^{\mathrm{T}}$ represent two distinct species of the genus Flavobacterium.

Colony morphology of the novel isolates cultivated on PYG agar at $14{ }^{\circ} \mathrm{C}$ for $9-10$ days was assessed. Gram staining was performed according to the method described by Gerhardt et al. (1994). Growth was tested on laboratoryprepared nutrient agar $(0.3 \%$ beef extract, $1 \%$ soy peptone, $0.5 \% \mathrm{NaCl})$, trypticase soy agar ( $1.5 \%$ tryptone, $0.5 \%$ soy peptone, $0.5 \% \mathrm{NaCl}$ ) and PYG agar at $14{ }^{\circ} \mathrm{C}$ after 7 days of 
incubation. Gliding motility was investigated by using the hanging-drop technique (Bernardet et al., 2002). Microaerobic and anaerobic growth were tested by using the Oxoid atmosphere generation system. The presence of flagella was observed under a transmission electron microscope (Hitachi $\mathrm{H}-600$ at $75 \mathrm{kV}$ ). The temperature range for growth was tested between 0 and $40{ }^{\circ} \mathrm{C}\left(1{ }^{\circ} \mathrm{C}\right.$ increments at $0-5$ and $16-25{ }^{\circ} \mathrm{C}$, and $5{ }^{\circ} \mathrm{C}$ increments outside these two ranges). The $\mathrm{pH}$ range for growth of the new isolates and reference strains was tested on PYG broth adjusted to $\mathrm{pH} 4-11$ (increments of $0.5 \mathrm{pH}$ units). Tolerance to salinity was determined by using $\mathrm{NaCl}-$ free PYG broth supplemented with $0-4 \%(w / v) ~ \mathrm{NaCl}$ (at $0.5 \%$ intervals) for 5-7 days at $14{ }^{\circ} \mathrm{C}$. Cells were tested for oxidase activity by determining the oxidation of $1 \%(\mathrm{w} / \mathrm{v})$ tetramethyl- $p$-phenylenediamine (Merck). Catalase activity was tested by monitoring the production of oxygen bubbles in a $3 \%(\mathrm{v} / \mathrm{v})$ aqueous hydrogen peroxide solution. Congo red adsorption and the detection of flexirubin-type pigments were tested following the methods of Bernardet et al. (2002).

The methods used to determine utilization of citrate and hydrolysis of gelatin, urea, DNA and starch followed Smibert \& Krieg (1981). Hydrolysis of casein, Tweens 20, 60 and 80 , aesculin and tyrosine was investigated according to the methods of Dong \& Cai (2001). Hydrolysis of alginate, chitin, pectin and carboxymethylcellulose was performed according to Reichenbach (1992). The production of a precipitate on egg yolk agar was tested on PYGbased medium supplemented with $50 \%$ egg yolk emulsion. Other physiological properties were tested by using the commercial API 20NE, API 20E and API ZYM systems (bioMérieux) according to the manufacturer's instructions. Utilization of carbon and energy sources was investigated by using a basal medium [containing $0.2 \%\left(\mathrm{NH}_{4}\right)_{2} \mathrm{SO}_{4}, 0.05 \%$ $\mathrm{NaH}_{2} \mathrm{PO}_{4} \cdot \mathrm{H}_{2} \mathrm{O}, 0.05 \% \mathrm{~K}_{2} \mathrm{HPO}_{4}, 0.02 \% \mathrm{MgSO}_{4} .7 \mathrm{H}_{2} \mathrm{O}$ and $\left.0.01 \% \mathrm{CaCl}_{2} \cdot 2 \mathrm{H}_{2} \mathrm{O}\right]$ supplemented with vitamins, as described by Green \& Bousfield (1982). The results of API ZYM tests were read after $4 \mathrm{~h}$ of incubation and the results of API 20NE and API 20E tests were read after 48-72 h. Acid production from carbohydrates was determined as described by Hugh \& Leifson (1953) over a period of 1 week. All tests were performed at $14{ }^{\circ} \mathrm{C}$ and the cells used in the tests were cultivated for 18-24 h. The biochemical and morphological characteristics of strains $\mathrm{Sr} 22^{\mathrm{T}}$ and $\mathrm{Sr} 25^{\mathrm{T}}$ are shown in Table 1 and in the species descriptions below.

Cellular fatty acids were tested for and analysed according to the instructions of the standard Microbial Identification (MIDI), Sherlock version 6.0, procedure (Sasser, 1990), with reference to the TSBA 6.0 database. Strains $\mathrm{Sr} 22^{\mathrm{T}}$ and $\mathrm{Sr} 25^{\mathrm{T}}$ and reference type strains were incubated on PYG medium at $14{ }^{\circ} \mathrm{C}$ for $48 \mathrm{~h}$. The predominant fatty acids of strain $\mathrm{Sr}_{22}{ }^{\mathrm{T}}$ were iso- $\mathrm{C}_{15: 1} \mathrm{G}(6.01 \%)$, iso- $\mathrm{C}_{15: 0}(8.93 \%)$, iso- $\mathrm{C}_{16: 1} \mathrm{H}(12.68 \%)$, iso- $\mathrm{C}_{16: 0}(10.4 \%), \mathrm{C}_{15: 1} \omega 6 c(8.97 \%)$, $\mathrm{C}_{17: 1} \omega 6 c(5.96 \%)$, iso- $\mathrm{C}_{16: 0} 3-\mathrm{OH}(11.14 \%)$ and summed feature 3 (comprising $\mathrm{C}_{16: 1} \omega 7 c$ and/or $\mathrm{C}_{16: 1} \omega 6 c, 12.33 \%$ ); those of strain $\mathrm{Sr}^{2} 5^{\mathrm{T}}$ were iso- $\mathrm{C}_{15: 0}(10.8 \%)$, anteiso- $\mathrm{C}_{15: 0}$ (5.23\%), $\mathrm{C}_{15: 1} \omega 6 c(11.79 \%), \mathrm{C}_{17: 1} \omega 6 c(5.43 \%)$, iso- $\mathrm{C}_{16: 0}$ $3-\mathrm{OH}(7.04 \%)$ and summed feature $3(20.42 \%)$. The fatty acid profiles of the novel isolates and of $F$. degerlachei NBRC $102677^{\mathrm{T}}, F$. omnivorum CGMCC $1.2747^{\mathrm{T}}, F$. tiangeerense CGMCC $1.6847^{\mathrm{T}}$, F. sinopsychrotolerans CGMCC $1.8704^{\mathrm{T}}, F$. fryxellicola LMG $22022^{\mathrm{T}}$ and F. xinjiangense CGMCC $1.2749^{\mathrm{T}}$ are detailed in Table 2.

Extraction and purification of respiratory quinones were performed as described by Collins (1985). Respiratory quinones were analysed by HPLC (Wu et al., 1989) with F. xinjiangense CGMCC $1.2749^{\mathrm{T}}$ as a reference. Cells of strains $\mathrm{Sr} 22^{\mathrm{T}}$ and $\mathrm{Sr} 25^{\mathrm{T}}$ contained MK- 6 as the major respiratory quinone, in accordance with data for members of the family Flavobacteriaceae (Bernardet \& Bowman, 2006). Polar lipids were extracted and analysed on silica gel plates (Kieselgel $60 \mathrm{~F}$; Merck) by twodimensional TLC (Kates, 1986). Pseudomonas mendocina CGMCC $1.1804^{\mathrm{T}}$ was used as a reference strain. In experiments to analyse respiratory quinones and polar lipids, strains $\operatorname{Sr} 22^{\mathrm{T}}$ and $\mathrm{Sr} 25^{\mathrm{T}}$ and the reference strains were incubated on PYG medium at $14{ }^{\circ} \mathrm{C}$ for $48 \mathrm{~h}$. The major polar lipid of strains $\mathrm{Sr} 22^{\mathrm{T}}$ and $\mathrm{Sr} 25^{\mathrm{T}}$ was phosphatidylethanolamine (Fig. S1, available in IJSEM Online), consistent with data for the genus Flavobacterium. Strain $\mathrm{Sr} 25^{\mathrm{T}}$ also contained phosphatidylcholine as a minor component.

The phylogenetic and phenotypic data presented here demonstrate that strains $\mathrm{Sr} 22^{\mathrm{T}}$ and $\mathrm{Sr} 25^{\mathrm{T}}$ represent two novel species of the genus Flavobacterium, for which the names Flavobacterium xueshanense sp. nov. and Flavobacterium urumqiense sp. nov. are proposed, respectively.

\section{Description of Flavobacterium xueshanense sp. nov.}

Flavobacterium xueshanense (xue.sha.nen'se. N.L. neut. adj. xueshanense pertaining to the region where the China No.1 glacier is located).

Cells are Gram-stain-negative, non-spore-forming, nongliding rods, $0.32-0.38 \mu \mathrm{m}$ wide and 1.04-2.08 $\mu \mathrm{m}$ long. Colonies grown on PYG agar for 9 days are circular, yellow, convex with entire margins and about $1.5 \mathrm{~mm}$ in diameter. Growth occurs on PYG, nutrient and trypticase soy agars. Aerobic growth is good and microaerobic growth is weak. Does not grow anaerobically. Growth occurs at $2-18{ }^{\circ} \mathrm{C}$ (optimum, $14{ }^{\circ} \mathrm{C}$ ). The $\mathrm{pH}$ range for growth is 6.0-9.0 (optimum, $\mathrm{pH} 7.0$ ). The salinity range for growth is $0-0.5 \% \mathrm{NaCl}$. Flexirubin-type pigments and brown diffusible pigment on L-tyrosine agar are not produced. Congo red is not absorbed. Catalase- and oxidase-positive. Hydrogen sulfide and indole are not produced. Nitrate is not reduced. No precipitate is formed on egg yolk agar. The methyl red and Voges-Proskauer tests are negative. Does not utilize citrate. Positive for hydrolysis of casein and aesculin, but negative for hydrolysis of gelatin, urea, tyrosine, starch, chitin, pectin, alginate, DNA, carboxymethylcellulose and Tweens 20, 60 and 80. Positive for naphthol-AS-BIphosphohydrolase, acid phosphatase, alkaline phosphatase, leucine arylamidase, valine arylamidase and $N$-acetyl$\beta$-glucosaminidase activities. Negative for $\beta$-glucosidase, 
Table 1. Differential characteristics between the novel isolates and the type strains of related species of the genus Flavobacterium

Strains: 1, Sr22 $2^{\mathrm{T}} ; 2$, Sr25 $5^{\mathrm{T}} ; 3$, F. sinopsychrotolerans CGMCC $1.8704^{\mathrm{T}} ; 4$, F. xinjiangense CGMCC $1.2749^{\mathrm{T}} ; 5$, F. omnivorum CGMCC $1.2747^{\mathrm{T}}$; 6 , F. fryxellicola LMG $22022^{\mathrm{T}}$; 7, F. degerlachei NBRC $102677^{\mathrm{T}}$; 8, F. tiangeerense CGMCC $1.6847^{\mathrm{T}}$. All data are from the present study. All strains were positive for: growth on nutrient agar and trypticase soy agar; hydrolysis of casein; enzyme activity of oxidase, catalase, alkaline phosphatase, acid phosphatase, leucine arylamidase, valine arylamidase and naphthol-AS-BI-phosphohydrolase; and utilization of starch, sodium glutamate and glycogen. All strains were negative for: hydrolysis of urea, alginate, chitin, pectin, DNA, tyrosine, carboxymethylcellulose and Tweens 20, 60 and 80 ; production of hydrogen sulfide, flexirubin-type pigments and indole; acid production from galactose, lactose, L-arabinose, melibiose, xylose, rhamnose, meso-erythritol, dulcitol, sorbitol, sorbose, salicin, mannitol, ribose, methyl $\alpha$-D-glucoside and glycerol; enzyme activity of cystine arylamidase, $\alpha$-galactosidase, esterase (C4), esterase lipase (C8), lipase (C14), trypsin, $\beta$-galactosidase, $\beta$-glucuronidase, $\alpha$-mannosidase and $\beta$ fucosidase; and utilization of D-mannitol, L-rhamnose, xylose, succinic acid, tartaric acid, meso-erythritol, fumarate, myo-inositol, sorbitol, methyl $\alpha$-D-glucoside, L-arabinose, melibiose and sodium acetate.

\begin{tabular}{|c|c|c|c|c|c|c|c|c|}
\hline Characteristic & 1 & 2 & 3 & 4 & 5 & 6 & 7 & 8 \\
\hline Growth at $18{ }^{\circ} \mathrm{C}$ & + & - & + & + & + & - & + & + \\
\hline Growth at $19{ }^{\circ} \mathrm{C}$ & - & - & + & + & + & - & + & + \\
\hline Growth on seawater agar & + & + & + & - & + & + & + & - \\
\hline Growth with $1.0 \% \mathrm{NaCl}$ & - & - & + & - & + & - & + & - \\
\hline Growth at $\mathrm{pH} 9.5$ & - & + & + & + & + & + & + & + \\
\hline \multicolumn{9}{|l|}{ Hydrolysis of: } \\
\hline Gelatin & - & + & - & + & - & - & - & - \\
\hline Aesculin & - & + & - & + & + & - & + & - \\
\hline Starch & - & - & + & + & + & + & + & + \\
\hline Voges-Proskauer reaction (API 20E) & - & - & + & + & + & - & + & - \\
\hline Assimilation of (API 20NE) N-acetyl-glucosamine & - & - & + & + & - & - & - & - \\
\hline \multicolumn{9}{|l|}{ Acid production from: } \\
\hline Glucose & + & + & + & + & - & + & + & + \\
\hline Mannose & + & + & - & + & - & - & + & + \\
\hline Maltose & + & + & + & + & - & - & + & + \\
\hline Raffinose & - & - & - & + & - & - & + & - \\
\hline Amygdalin & - & - & - & - & - & - & + & - \\
\hline Starch & + & + & + & + & - & - & + & + \\
\hline Cellobiose & - & - & - & + & - & - & + & - \\
\hline Trehalose & - & - & - & + & - & + & - & - \\
\hline Sucrose & - & + & + & + & - & - & - & + \\
\hline Inulin & - & - & - & + & - & - & - & - \\
\hline Fructose & - & - & + & - & - & - & - & - \\
\hline Melizitose & - & + & - & + & - & - & - & - \\
\hline \multicolumn{9}{|l|}{ Enzyme activities } \\
\hline$\alpha$-Glucosidase & - & + & + & + & + & + & + & - \\
\hline$\beta$-Glucosidase & - & - & - & + & - & - & - & - \\
\hline$\alpha$-Chymotrypsin & - & - & + & - & - & - & - & - \\
\hline$N$-Acetyl- $\beta$-glucosaminidase & + & - & + & - & - & - & - & - \\
\hline \multicolumn{9}{|l|}{ Utilization of: } \\
\hline Maltose & + & + & + & + & + & - & + & + \\
\hline Cellobiose & - & - & - & + & - & - & + & + \\
\hline$\alpha$-D-Glucose & - & + & + & + & + & - & + & - \\
\hline D-Mannose & - & + & + & + & - & - & + & + \\
\hline D-Raffinose & - & - & - & - & + & - & - & - \\
\hline Trehalose & - & - & - & + & + & - & + & - \\
\hline Melizitose & - & + & - & + & - & - & - & - \\
\hline Glycerol & - & - & - & - & + & - & - & - \\
\hline Sodium pyruvate & - & + & + & - & + & + & + & - \\
\hline D-Galactose & - & - & - & - & + & - & - & + \\
\hline Sucrose & - & + & + & + & + & - & + & + \\
\hline
\end{tabular}

$\alpha$-chymotrypsin, trypsin, esterase lipase (C8), esterase (C4), lipase (C14), cystine arylamidase, $\beta$-glucuronidase, $\beta$ galactosidase, $\alpha$-mannosidase, $\beta$-fucosidase, $\alpha$-galactosidase, $\alpha$-glucosidase and chymotrypsin activities. Acids are produced from starch, glucose, mannose and maltose but not from melezitose, sucrose, cellobiose, sorbitol, 
Table 2. Cellular fatty acid compositions (\%) of strains $\mathrm{Sr}_{2} 2^{\top}$ and $\mathrm{Sr}_{25}{ }^{\top}$ and their closest phylogenetic neighbours in the genus Flavobacterium

Strains: 1 , Sr $22^{\mathrm{T}} ; 2$, Sr25 $5^{\mathrm{T}} ; 3$, F. sinopsychrotolerans CGMCC $1.8704^{\mathrm{T}} ; 4$, F. xinjiangense CGMCC $1.2749^{\mathrm{T}} ; 5$, F. omnivorum CGMCC $1.2747^{\mathrm{T}}$; 6 , F. fryxellicola LMG $22022^{\mathrm{T}}$; 7, F. degerlachei NBRC $102677^{\mathrm{T}} ; 8$, F. tiangeerense CGMCC $1.6847^{\mathrm{T}}$. All data are from this study. Fatty acids amounting to $<1 \%$ of the total in all strains are not shown. tr, Trace $(<1 \%)$; ND, not detected.

\begin{tabular}{|c|c|c|c|c|c|c|c|c|}
\hline Fatty acid & 1 & 2 & 3 & 4 & 5 & 6 & 7 & 8 \\
\hline \multicolumn{9}{|c|}{ Saturated straight-chain } \\
\hline $\mathrm{C}_{13: 0}$ & $\mathrm{ND}$ & $\operatorname{tr}$ & $\operatorname{tr}$ & $\operatorname{tr}$ & $\operatorname{tr}$ & 1.10 & $\operatorname{tr}$ & $\operatorname{tr}$ \\
\hline $\mathrm{C}_{16: 0}$ & 1.06 & 2.53 & 2.04 & 2.16 & 2.05 & 5.04 & 4.19 & 2.60 \\
\hline \multicolumn{9}{|l|}{ Saturated branched } \\
\hline iso- $\mathrm{C}_{13: 0}$ & $\operatorname{tr}$ & $\operatorname{tr}$ & $\operatorname{tr}$ & 1.42 & $\operatorname{tr}$ & $\operatorname{tr}$ & $\operatorname{tr}$ & $\operatorname{tr}$ \\
\hline iso- $\mathrm{C}_{15: 1} \mathrm{G}$ & 6.01 & 3.10 & 6.51 & 4.09 & 7.96 & 7.16 & 5.70 & 7.49 \\
\hline anteiso- $\mathrm{C}_{15: 1} \mathrm{~A}$ & $\operatorname{tr}$ & $\operatorname{tr}$ & $\operatorname{tr}$ & $\operatorname{tr}$ & $\operatorname{tr}$ & $\operatorname{tr}$ & 1.00 & $\operatorname{tr}$ \\
\hline iso- $\mathrm{C}_{15: 0}$ & 8.93 & 10.80 & 12.32 & 12.91 & 16.10 & 18.08 & 8.71 & 21.36 \\
\hline anteiso- $\mathrm{C}_{15: 0}$ & 1.04 & 5.23 & 9.51 & 4.07 & 3.99 & 4.97 & 10.63 & 4.97 \\
\hline iso- $\mathrm{C}_{16: 1} \mathrm{H}$ & 12.68 & 3.82 & 2.78 & 2.42 & 4.96 & 3.60 & 1.52 & 2.96 \\
\hline iso- $\mathrm{C}_{16: 0}$ & 10.40 & 2.13 & 2.38 & 2.11 & 4.73 & 5.16 & 1.11 & 2.14 \\
\hline $\mathrm{C}_{17: 1} \omega 8 c$ & $\operatorname{tr}$ & $\operatorname{tr}$ & $\operatorname{tr}$ & 1.26 & $\operatorname{tr}$ & $\operatorname{tr}$ & 1.36 & $\operatorname{tr}$ \\
\hline $\mathrm{C}_{18: 1} \omega 5 c$ & $\operatorname{tr}$ & $\operatorname{tr}$ & 1.03 & $\operatorname{tr}$ & 1.13 & $\operatorname{tr}$ & $\mathrm{ND}$ & $\operatorname{tr}$ \\
\hline \multicolumn{9}{|l|}{ Hydroxy } \\
\hline $\mathrm{C}_{15: 0} 2-\mathrm{OH}$ & $\operatorname{tr}$ & 1.38 & $\operatorname{tr}$ & 1.22 & $\operatorname{tr}$ & $\operatorname{tr}$ & $\operatorname{tr}$ & $\operatorname{tr}$ \\
\hline $\mathrm{C}_{15: 0} 3-\mathrm{OH}$ & ND & 1.54 & 1.83 & 1.26 & $\mathrm{ND}$ & $\mathrm{ND}$ & 1.49 & $\mathrm{ND}$ \\
\hline iso- $\mathrm{C}_{16: 0} 3-\mathrm{OH}$ & 11.14 & 7.04 & 9.99 & 5.55 & 4.93 & 6.81 & 3.45 & 4.62 \\
\hline $\mathrm{C}_{16: 0} 3-\mathrm{OH}$ & 1.09 & 1.08 & 1.04 & 1.62 & $\operatorname{tr}$ & 1.74 & 1.59 & 1.12 \\
\hline iso- $\mathrm{C}_{17: 0} 3-\mathrm{OH}$ & 3.25 & 3.28 & 5.50 & 3.43 & 5.42 & 5.44 & 3.54 & 4.10 \\
\hline \multicolumn{9}{|l|}{ Summed features ${ }^{*}$} \\
\hline 3 & 12.33 & 20.42 & 7.33 & 20.42 & 10.93 & 11.13 & 15.18 & 10.41 \\
\hline 4 & 1.57 & $\mathrm{ND}$ & $\mathrm{ND}$ & $\mathrm{ND}$ & 1.64 & 1.09 & ND & 1.57 \\
\hline
\end{tabular}

${ }^{*}$ Summed features are groups of two or three fatty acids that cannot be separated by GLC with the MIDI system (Sherlock version 6.0). Summed feature 3 comprised $\mathrm{C}_{16: 1} \omega 7 c$ and/or $\mathrm{C}_{16: 1} \omega 6 c$; summed feature 4 comprised iso- $\mathrm{C}_{17: 1}$ I/anteiso $\mathrm{B}$; summed feature 9 comprised iso- $\mathrm{C}_{17: 1} \omega 9 c$ and/ or 10-methyl $\mathrm{C}_{16: 0}$.

glycerol, melibiose, sorbose, galactose, rhamnose, mannitol, trehalose, lactose, glycogen, methyl $\alpha$-D-glucoside, meso-erythritol, amygdalin, xylose, L-arabinose, fructose or inulin. Utilizes maltose as sole carbon source. The predominant fatty acids are iso- $\mathrm{C}_{15: 1} \mathrm{G}$, iso- $\mathrm{C}_{15: 0}$, iso$\mathrm{C}_{16: 1} \mathrm{H}$, iso- $\mathrm{C}_{16: 0}, \mathrm{C}_{15: 1} \omega 6 c, \mathrm{C}_{17: 1} \omega 6 c$, iso- $\mathrm{C}_{16: 0} 3-\mathrm{OH}$ and summed feature 3 (comprising $\mathrm{C}_{16: 1} \omega 7 c$ and/or $\mathrm{C}_{16: 1} \omega 6 c$ ). The major polar lipid is phosphatidylethanolamine. The DNA $\mathrm{G}+\mathrm{C}$ content of the type strain is $37.2 \mathrm{~mol} \%$.

The type strain, Sr $22^{\mathrm{T}}\left(=\mathrm{CGMCC} 1.9227^{\mathrm{T}}=\mathrm{NBRC}\right.$ $106479^{\mathrm{T}}$ ), was isolated from water of melted ice of the China No.1 glacier, Xinjiang Uygur Autonomous Region, China.

\section{Description of Flavobacterium urumqiense sp. nov.}

Flavobacterium urumqiense (ur.um.qi.en'se. N.L. neut. adj. urumqiense pertaining to the capital of the Xinjiang Uygur Autonomous Region).

Cells are Gram-stain-negative, non-spore-forming, nongliding rods, $0.42-0.44 \mu \mathrm{m}$ wide and $1.01-1.80 \mu \mathrm{m}$ long. Colonies grown on PYG agar for 9 days are circular, yellow, convex with entire margins and about $3.0 \mathrm{~mm}$ in diameter. Growth occurs on PYG, nutrient and trypticase soy agars. Aerobic growth is good and microaerobic growth is weak. Does not grow anaerobically. Growth occurs at 2$17{ }^{\circ} \mathrm{C}$ (optimum, $14-15{ }^{\circ} \mathrm{C}$ ). The $\mathrm{pH}$ range for growth is 
6.0-9.5 (optimum, $\mathrm{pH} 7.0$ ). The salinity range for growth is $0-0.5 \% \mathrm{NaCl}$. Flexirubin-type pigments and brown diffusible pigment on L-tyrosine agar are not produced. Congo red is not absorbed. Catalase- and oxidase-positive. Hydrogen sulfide and indole are not produced. Nitrate is not reduced. No precipitate is formed on egg yolk agar. The methyl red and Voges-Proskauer tests are negative. Does not utilize citrate. Positive for hydrolysis of casein, gelatin and aesculin, but negative for hydrolysis of urea, tyrosine, starch, chitin, pectin, alginate, DNA, carboxymethylcellulose and Tweens 20, 60 and 80. Positive for naphthol-AS-BIphosphohydrolase, acid phosphatase, alkaline phosphatase, leucine arylamidase, valine arylamidase and $\alpha$-glucosidase activities. Negative for $\beta$-glucosidase, $\alpha$-chymotrypsin, trypsin, esterase lipase (C8), esterase (C4), lipase (C14), cystine arylamidase, $\beta$-glucuronidase, $\beta$-galactosidase, $\alpha$ mannosidase, $\beta$-fucosidase, $N$-acetyl- $\beta$-glucosaminidase, $\alpha$-galactosidase and chymotrypsin activities. Acids are produced from starch, melezitose, sucrose, glucose, mannose and maltose but not from cellobiose, sorbitol, glycerol, melibiose, sorbose, galactose, rhamnose, mannitol, trehalose, lactose, glycogen, methyl $\alpha$-D-glucoside, meso-erythritol, amygdalin, xylose, L-arabinose, fructose or inulin. Utilizes D-mannose, cellobiose, $\alpha$-D-glucose, sucrose, maltose, starch, glycogen, melizitose, amygdalin, salicin, sodium pyruvate and sodium glutamate as sole carbon source; weak growth with trehalose and sodium acetate. The major respiratory quinone is menaquinone- 6 . The major fatty acids ( $>5 \%$ of the total) are iso- $\mathrm{C}_{15: 0}$, anteiso- $\mathrm{C}_{15: 0}$, $\mathrm{C}_{15: 1} \omega 6 c, \mathrm{C}_{17: 1} \omega 6 c$, iso- $\mathrm{C}_{16: 0} 3-\mathrm{OH}$ and summed feature 3 . The major polar lipid is phosphatidylethanolamine; phosphatidylcholine is present as a minor component. The DNA $\mathrm{G}+\mathrm{C}$ content of the type strain is $35.1 \mathrm{~mol} \%$.

The type strain, Sr25 ${ }^{\mathrm{T}} \quad\left(=\mathrm{CGMCC} 1.9230^{\mathrm{T}}=\mathrm{NBRC}\right.$ $106480^{\mathrm{T}}$ ), was isolated from water of melted ice of the China No.1 glacier, Xinjiang Uygur Autonomous Region, China.

\section{Acknowledgements}

This work was supported by the Knowledge Innovation Program of Chinese Academy of Sciences (grant no. KSCXZ-YW-Z-0937) and the National Natural Science Foundation of China (NSFC, no. 31070001).

\section{References}

Bergey, D. H., Harrison, F. C., Breed, R. S., Hammer, B. W. \& Huntoon, F. M. (editors) (1923). Genus II. Flavobacterium gen. nov. In Bergey's Manual of Determinative Bacteriology, pp. 97-117. Baltimore: Williams \& Wilkins.

Bernardet, J. F. \& Bowman, J. P. (2006). The genus Flavobacterium. In The Prokaryotes: a Handbook on the Biology of Bacteria, 3rd edn, vol. 7, pp. 481-531. Edited by M. Dworkin, S. Falkow, E. Rosenberg, K. H. Schleifer \& E. Stackebrandt. New York: Springer.

Bernardet, J.-F., Segers, P., Vancanneyt, M., Berthe, F., Kersters, K. \& Vandamme, P. (1996). Cutting a Gordian knot: emended classification and description of the genus Flavobacterium, emended description of the family Flavobacteriaceae, and proposal of Flavobacterium hydatis nom. nov. (basonym, Cytophaga aquatilis Strohl and Tait 1978). Int J Syst Bacteriol 46, 128-148.

Bernardet, J. F., Nakagawa, Y. \& Holmes, B. for the Subcommittee on the taxonomy of Flavobacterium and Cytophaga-like bacteria of the International Committee on Systematics of Prokaryotes (2002). Proposed minimal standards for describing new taxa of the family Flavobacteriaceae and emended description of the family. Int $J$ Syst Evol Microbiol 52, 1049-1070.

Collins, M. D. (1985). Isoprenoid quinone analysis in classification and identification. In Chemical Methods in Bacterial Systematics, pp. 267-287. Edited by M. Goodfellow \& D. E. Minnikin. London: Academic Press.

De Ley, J., Cattoir, H. \& Reynaerts, A. (1970). The quantitative measurement of DNA hybridization from renaturation rates. Eur $J$ Biochem 12, 133-142.

Dong, X. \& Cai, M. (editors) (2001). Systematic Bacteriological Manual. Beijing: Science Press. (in Chinese)

Felsenstein, J. (1981). Evolutionary trees from DNA sequences: a maximum likelihood approach. J Mol Evol 17, 368-376.

Gerhardt, P., Murray, R. G. E., Wood, W. A. \& Krieg, N. R. (1994). Phenotypic characterization. In Methods for General and Molecular Bacteriology, pp. 607-654. Edited by P. Gerhardt. Washington, DC: American Society for Microbiology.

Green, P. N. \& Bousfield, I. J. (1982). A taxonomic study of some Gram-negative facultatively methylotrophic bacteria. J Gen Microbiol 128, 623-638.

Hugh, R. \& Leifson, E. (1953). The taxonomic significance of fermentative versus oxidative metabolism of carbohydrates by various gram negative bacteria. J Bacteriol 66, 24-26.

Kates, M. (1986). Techniques of Lipidology, 2nd edn. Amsterdam: Elsevier.

Kimura, M. (1980). A simple method for estimating evolutionary rates of base substitutions through comparative studies of nucleotide sequences. J Mol Evol 16, 111-120.

Kumar, S., Tamura, K. \& Nei, M. (2004). MEGA3: integrated software for molecular evolutionary genetics analysis and sequence alignment. Brief Bioinform 5, 150-163.

Lane, D. J. (1991). 16S/23S rRNA sequencing. In Nucleic Acid Techniques in Bacterial Systematics, pp. 115-175. Edited by E. Stackebrandt \& M. Goodfellow. London: Wiley.

Marmur, J. (1961). A procedure for the isolation of deoxyribonucleic acid from micro-organisms. J Mol Biol 3, 208-218.

Marmur, J. \& Doty, P. (1962). Determination of the base composition of deoxyribonucleic acid from its thermal denaturation temperature. J Mol Biol 5, 109-118.

McCammon, S. A. \& Bowman, J. P. (2000). Taxonomy of Antarctic Flavobacterium species: description of Flavobacterium gillisiae sp. nov., Flavobacterium tegetincola sp. nov., and Flavobacterium xanthum sp. nov., nom. rev. and reclassification of [Flavobacterium] salegens as Salegentibacter salegens gen. nov., comb. nov. Int J Syst Evol Microbiol 50, 1055-1063.

Reichenbach, H. (1992). The order Cytophagales. In The Prokaryotes, 2nd edn, vol. 4, pp. 3631-3675. Edited by A. Balows, H. G. Trüper, M. Dworkin, W. Harder \& K. H. Schleifer. New York: Springer.

Saitou, N. \& Nei, M. (1987). The neighbor-joining method: a new method for reconstructing phylogenetic trees. Mol Biol Evol 4, 406-425.

Sasser, M. (1990). Identification of bacteria by gas chromatography of cellular fatty acids, MIDI Technical Note 101. Newark, DE: MIDI Inc.

Smibert, R. M. \& Krieg, N. R. (1981). General characterization. In Manual of Methods for General Bacteriology, pp. 409-443. Edited by 
P. Gerhardt, R. G. E. Murray, R. N. Costilow, E. W. Nester, W. A. Wood, N. R. Krieg \& G. B. Phillips. Washington, DC: American Society for Microbiology.

Tamaki, H., Hanada, S., Kamagata, Y., Nakamura, K., Nomura, N., Nakano, K. \& Matsumura, M. (2003). Flavobacterium limicola sp. nov., a psychrophilic, organic-polymer-degrading bacterium isolated from freshwater sediments. Int J Syst Evol Microbiol 53, 519-526.

Wu, C., Lu, X., Qin, M., Wang, Y. \& Ruan, J. (1989). Analysis of menaquinone compound in microbial cells by HPLC. Microbiology [English translation of Microbiology (Beijing)] 16, 176-178.

Xin, Y.-H., Liang, Z.-H., Zhang, D.-C., Liu, H.-C., Zhang, J.-L., Yu, Y., Xu, M.-S., Zhou, P.-J. \& Zhou, Y.-G. (2009). Flavobacterium tiangeerense sp. nov., a cold-living bacterium isolated from a glacier. Int J Syst Evol Microbiol 59, 2773-2777.

Yoon, J.-H., Kang, S.-J. \& Oh, T.-K. (2006). Flavobacterium soli sp. nov., isolated from soil. Int J Syst Evol Microbiol 56, 997-1000.

Zhang, D.-C., Wang, H.-X., Liu, H.-C., Dong, X.-Z. \& Zhou, P.-J. (2006). Flavobacterium glaciei sp. nov., a novel psychrophilic bacterium isolated from the China No.1 glacier. Int J Syst Evol Microbiol 56, 2921-2925.

Zhu, F., Wang, S. \& Zhou, P. (2003). Flavobacterium xinjiangense sp. nov. and Flavobacterium omnivorum sp. nov., novel psychrophiles from the China No. 1 glacier. Int J Syst Evol Microbiol 53, 853-857. 